\title{
HUBUNGAN STRES DENGAN KUALITAS HIDUP PADA OSTOMATE USUS DI RSUP DR. M. DJAMIL PADANG
}

\author{
Nike Puspita Alwi ${ }^{1)}$ \\ ${ }^{1}$ STIKes SYEDZA SAINTIKA Padang \\ nikealwi@gmail.com
}

Diterima: September 2018 Diterbitkan: Desember 2018

\begin{abstract}
Abstrak
Keberadaan stoma memberikan berbagai perubahan dan tekanan pada ostomate. Beberapa stresor seperti flatus, suara pergerakan usus, bau dan kontrol defekasi stoma dapat mencetuskan stres pada ostomate. Keadaan tersebut mampu mempengaruhi kualitas hidup ostomate pada akhirnya. Kualitas hidup pada ostomate merupakan persepsi yang subjektif mengenai aspek positif dan negatif yang meliputi fisik, emosional, sosial dan fungsi kognitif, gejala dan efek terhadap keberadaan stoma. Tujuan penelitian ini adalah untuk mengetahui hubungan antara stres dengan kualitas hidup pada ostomate. Penelitian ini bersifat korelasional dengan pendekatan cross sectional dengan responden sebanyak 28 orang dari RSUP DR. M. Djamil Padang yang didapatkan dengan menggunakan teknik accidental sampling selama satu bulan. Data dikumpulkan melalui kuesioner yang menggunakan skala likert untuk variabel stress dan kualitas hidup. Analisa data univariat dilakukan dengan distribusi frekuensi dan bivariat dengan uji Spearman. Hasil penelitian menunjukkan sebanyak $67,9 \%$ responden mengalami stres sedang, 64,3\% responden memiliki kualitas hidup yang cukup. Terdapat hubungan positif dan sangat kuat $(\mathrm{r}=0,826)$ antara stres dan kualitas hidup pada ostomate. Penting bagi ostomate untuk mendapatkan konseling, penyuluhan dan dukungan dari keluarga untuk membantu dalam menghadapi perubahan-perubahan yang dialami sehingga stres dapat diminimalkan dan kualitas hidup mereka menjadi lebih baik.
\end{abstract}

Kata Kunci : Ostomate; stress dan kualitas hidup

\begin{abstract}
The presence of stoma gives many changes and pressure to ostomate. Stressors such as flatus, noises of bowel moving, odors and defecation control could affect stress to ostomate. That condition could affect to their quality of life. The aim of this research was to examine the correlation between stress and quality of life of ostomate. This research was correlational study with cross sectional approach conducted to 28 respondents from DR. M. Djamil hospital were obtained by accidental sampling technique for a month. Data were collected by questionnaire that using Likert scale to stress and quality of life variable. Univariate analysis was done by frequency distribution and bivariate analysis by Spearman test. The result of this research showed that 67,9\% respondents experiencing mild stress, $64,3 \%$ respondents have mild quality of life. There was a positive and very strong correlation $(r=0,826)$ between stress and quality of life to ostomate. It is important to have counselling in order to face changing experience to ostomate so that stress could be minimalized and better quality of life.
\end{abstract}

Keywords: Ostomate; stress and quality of life 


\section{PENDAHULUAN}

Stoma atau lebih dikenal dengan istilah ostomi adalah pembukaan pada permukaan tubuh dimana sebuah organ dibawa ke luar (Blackley, 2004). Ostomi merupakan pembedahan pada tubuh untuk mengeluarkan sampah tubuh, ketika seseorang kehilangan fungsi normal dalam eliminasi pada pencernaan atau urinasi, yang disebabkan oleh defek kongenital, kecelakaan atau penyakit (United Ostomy Associations of America [UOAA], 2009). Menurut Hedrick (1989 dikutip dari Teneyck, 1997), operasi yang menghasilkan ostomi abdominal mempunyai dampak yang besar terhadap perubahan eliminasi. Indikasi pembedahan stoma pada pencernaan adalah: kanker kolorekti, radang usus, gangguan iskemik saluran pencernaan, trauma usus, obstruksi usus besar, gangguan defekasi. Menurut Mihalopuolas (1994 dikutip dari Teneyck, 1997), perkiraan semua operasi ostomi di dunia adalah 100.000 tiap tahunnya.

Menurut Kluka dan Kristjanson (1996 dikutip dari Teneyck, 1997) operasi ostomi ini menghasilkan perubahan fisik dan psikologis yang berakibat pada gaya hidup, gambaran diri dan konsep diri seseorang. Menurut Mihalopoulos (1994 dikutip dari Potter, P.A., \& Perry, 2005) mengatakan bahwa bau busuk, tumpahan atau kebocoran feses yang encer, dan ketidakmampuan mengatur defekasi membuat ostomate (orang dengan ostomi usus) kehilangan harga dirinya.

Hasil penelitian Tseng, Wang, Chin, dkk (2000 dikutip dari Tseng, H.C., Wang, H.H., Hsu, Y.Y., \& Weng, 2004) tentang stres pada pasien kolostomi permanen yang, menyatakan bahwa stres pada pasien dengan kolostomi dapat ditimbulkan dari perubahan status fisik $(22,8 \%)$, dari perubahan interaksi dalam anggota keluarga $(6,5 \%)$, dari konsep diri $(5,8 \%)$, dan dari perawatan kolostomi itu sendiri $(5 \%)$. Kemudian pada penelitian selanjutnya dari $53,4 \%$ pasien yang bekerja sebelum mereka menggunakan kantong kolostomi hanya $16,4 \%$ yang kembali bekerja setelah dipasang kantong kolostomi, sedangkan $37 \%$ nya berhenti bekerja setelah dipasang kantong.

Sebuah studi tentang perasaan jijik, stigma dan penyesuaian terhadap hidup pada pasien kolostomi mengatakan bahwa terdapat hubungan yang sangat kuat antara perasaan jijik dengan kepuasan hidup (hubungan yang negatif atau berbanding terbalik), dan hubungan yang sama juga terjadi terhadap kualitas hidup pasien dengan kolostomi (Smith dkk, 2007). Beberapa peneliti telah mengidentifikasi dan menggambarkan masalah psikososial yang dihadapi ostomate dapat mempengaruhi seluruh kualitas hidupnya (Bekkers dkk, 1996; Borwell, 1997; Huish dkk, 1998; \& Rozmovits, 2004 dikutip dari Sirota, 2006).

Di Indonesia, penelitian tentang kualitas hidup pada pasien yang menjalani pemasangan stoma usus telah dilakukan di kota Bandung, dimana sebagian besar subjek penelitian mempersepsikan tingkat kualitas hidupnya berada pada rentang sangat kurang sampai cukup (Priambodo, Ibrahim, \& Nuraen, 2007).

Melalui wawancara peneliti dengan perawat IRNA bedah RSUP DR. M. Djamil Padang, Deliana, tentang discharge planning pada pasien post kolostomi yang dilakukan pada tanggal 18 April 2009, pasien post kolostomi hanya diberikan jadwal kemoterapi. Dilihat dari dukungan setelah post ostomi, ostomate di daerah Sumbar belum memiliki badan oganisasi khusus untuk mendukung para ostomate agar mampu merehabilitasi diri terhadap perubahan yang telah dialami. Padahal melalui badan seperti inilah sebenarnya ostomate memiliki kesempatan untuk dapat saling berbagi dan menguatkan (Maguire \& Parkes, 1998).

Deliana menyatakan bahwa pasien ada yang pernah menolak untuk dilakukan pembuatan stoma karena merasa akan 
adanya ancaman stres akibat perubahan letak pembuangan (Komunikasi personal, 18 April 2009). Berdasarkan hasil wawancara awal peneliti pada tanggal 18 April 2009 dengan empat orang pasien di IRNA B yang menggunakan kolostomi mengatakan merasa tidak percaya diri dengan keadaan dirinya yang buang air besar tidak seperti orang lain yang normal, pasien merasa merasa dirinya bau karena sering flatus dan ususnya berbunyi, dan keberadaan stoma menjadi penghalang pasien untuk beribadah (shalat) karena ragu dengan kebersihan dirinya bahkan pasien mengatakan tidak pernah shalat lagi semenjak memiliki stoma, mengganggu dalam berinteraksi sosial seperti berkumpul dengan tetangga atau teman yang menjenguk, dan aktivitas tidur walaupun sebelumnya kantong telah dikosongkan namun pasien mengatakan kadang tidak sadar bahwa feses atau flatus tiba-tiba saja keluar dari stoma yang juga disertai oleh bau yang tidak mengenakkan.

\section{METODE PENELITIAN}

Jenis penelitian yang digunakan adalah korelasi dengan pendekatan cross sectional. Penngumpulan data dilakukan peneliti di Unit Rawat Jalan poliklinik bedah dan IRNA B wanita dan pria RSUP DR. M. DJAMIL dimana waktu pengambilan data penelitian dilakukan dari tanggal 2 Agustus sampai 5 September 2009. Populasi penelitian ini yakni semua ostomate usus di poliklinik bedah yang berjumlah 82 orang pada bulan April- Juni 2009 dan IRNA B wanita dan pria RSUP DR. M. Djamil Padang yang berjumlah 78 orang pada tahun 2008. Teknik sampel yang digunakan peneliti adalah accidental sampling dengan memenuhi kriteria yang ditetapkan oleh peneliti berupa: sedang menggunakan kantong ostomi, telah menjalani keseharian di rumah, dapat berinteraksi dan berkomunikasi dengan baik dan bersedia menjadi responden.
Teknik pengumpulan data dilakukan menggunakan kuesioner yang terdiri dari 20 pernyataan mengenai stres ostomate dan 14 pertanyaan ditinjau dari fungsi biologis, psikologis, sosial dan spiritual. Adapun 3 kategori tingkat stres yang digunakan peneliti yakni:

stres ringan: 0-27,

stres sedang: $28-54$,

stres berat : 55-81.

Sementara variabel kualitas hidup memiliki 3 kategori, yakni:

kualitas hidup baik: 0-19,

kualitas hidup cukup: 20-38 dan

kualitas hidup buruk: 39-57.

Pengolahan data dilakukan peneliti dengan memeriksa data (editing), mengkode data (coding), memasukan data (entry), membersihkan data (cleanning), serta memasukan data (tabulating). Analisa data yang digunakan adalah analisa univariat adalah dengan menentukan distribusi frekuensi dari variabel penghasilan, lama stoma dan tingkat stres ostomate. Sedangkan analisa bivariat dengan menguji dua variabel yaitu independen (tingkat stres) dengan variabel dependen (kualitas hidup) dengan menggunakan uji Spearman.

\section{HASIL PENELITIAN}

\section{Analisis Univariat}

Dari tabel 1 dapat diperoleh informasi bahwa $67,9 \%$ responden mengalami stres sedang.

Tabel 1

\section{Distribusi Frekuensi Stres Pada} Ostomate

\begin{tabular}{cccc}
\hline $\mathbf{N}$ & Stres & $\begin{array}{c}\text { Frekuensi } \\
\text { (n) }\end{array}$ & $\begin{array}{c}\text { Persentase } \\
(\mathbf{\% )}\end{array}$ \\
\hline 1. & Ringan & 8 & 28,6 \\
2. & Sedang & 19 & 67,9 \\
3. & Berat & 1 & 3,6 \\
\hline & Jumlah & 28 & 100,0 \\
\hline
\end{tabular}


Dari tabel 2 dapat diperoleh informasi bahwa $64,3 \%$ responden memiliki kualitas hidup yang cukup.

Tabel 2

Distribusi Frekuensi Kualitas hidup pada Ostomate

\begin{tabular}{|c|c|c|c|}
\hline $\mathbf{N}$ & $\begin{array}{c}\text { Kualitas } \\
\text { hidup }\end{array}$ & $\begin{array}{c}\text { Frekuensi } \\
\text { (n) }\end{array}$ & $\begin{array}{c}\text { Persentase } \\
(\%)\end{array}$ \\
\hline 1. & Baik & 10 & 35,7 \\
\hline 2. & Cukup & 18 & 64,3 \\
\hline 3. & Buruk & 0 & 0,0 \\
\hline & Jumlah & 28 & 100,0 \\
\hline
\end{tabular}

2. Analisis Bivariat

\section{PEMBAHASAN}

\section{STRES}

Hasil penelitian menunjukkan lebih separuh responden mengalami stress sedang karena stomanya. Ini menunjukkan bahwa responden belum cukup mampu dalam membangun koping untuk menghadapi perubahan-perubahan yang terjadi. Blackley (2004) berpendapat bahwa mekanisme koping adalah pikiran dan sikap yang digunakan untuk mengatasi stres dan ansietas.

Tabel 3

Analisis Hubungan Lama Stoma dengan Tingkat Stres Ostomate $(\mathrm{n}=\mathbf{2 8})$

\begin{tabular}{|c|c|c|c|c|c|c|c|c|}
\hline \multirow{3}{*}{ Stres } & \multicolumn{6}{|c|}{ Kualitas Hidup } & \multicolumn{2}{|c|}{ Total } \\
\hline & \multicolumn{2}{|c|}{ Baik } & \multicolumn{2}{|c|}{ Cukup } & \multicolumn{2}{|c|}{ Buruk } & \multirow{2}{*}{$\begin{array}{c}\text { Frek. } \\
\text { (n) }\end{array}$} & \multirow{2}{*}{$\begin{array}{c}\text { Persentase } \\
(\%)\end{array}$} \\
\hline & $\begin{array}{c}\text { Frek. } \\
\text { (n) }\end{array}$ & $\begin{array}{c}\text { Persentase } \\
(\%)\end{array}$ & $\begin{array}{c}\text { Frek. } \\
\text { (n) }\end{array}$ & $\begin{array}{c}\text { Persentase } \\
(\%)\end{array}$ & $\begin{array}{c}\text { Frek. } \\
\text { (n) }\end{array}$ & $\begin{array}{c}\text { Persentase } \\
(\%)\end{array}$ & & \\
\hline Ringan & 8 & 100,0 & 0 & 0,0 & 0 & 0 & 8 & 28,6 \\
\hline Sedang & 2 & 10,5 & 17 & 89,5 & 0 & 0 & 19 & 67,9 \\
\hline Berat & 0 & 0,0 & 1 & 100,0 & 0 & 0 & 1 & 3,6 \\
\hline \multirow[t]{2}{*}{ Jumlah } & 10 & & 18 & & 0 & & 28 & 100,0 \\
\hline & $\mathrm{P}=0$, & & & & & & 0,826 & \\
\hline
\end{tabular}

Dari tabel 3 dapat dilihat bahwa seluruh responden yang mengalami stres ringan memiliki kualitas hidup yang baik. Sedangkan dari 19 responden yang mengalami stres sedang, hampir seluruhnya (17 responden) memiliki kualitas hidup yang cukup $(89,5 \%)$. Selanjutnya seluruh responden yang mengalami stres berat memiliki kualitas hidup yang cukup Dari hasil uji statistik Spearman diketahui terdapat hubungan positif dan sangat kuat antara stres dengan kualitas hidup ostomate dimana semakin tinggi skor nilai stres maka semakin tinggi pulalah skor nilai kualitas hidup ostomate atau semakin berat stres yang dirasakan semakin buruk kualitas hidup yang dimiliki ostomate karena nilai korelasi yang diperoleh adalah 0,826 .
Dari penelitian ini pun terlihat $28,6 \%$ responden mengalami stres ringan. Hal ini berarti responden tersebut mampu membangun koping yang efektif sehingga stresor yang muncul tidak mampu membawa responden pada keadaan stres yang lebih berat. Menurut (Rasmun, 2004) koping yang efektif dapat menghasilkan adaptasi yang menetap yang merupakan kebiasaan baru dan perbaikan dari situasi yang lama.

Dalam penelitian ini dari 28 responden hanya 3,6 \% responden yang mengalami stres berat. Hal ini berarti responden tersebut tidak mampu mengkoping stresor-stresor yang muncul terkait dengan stomanya seperti stresor dari flatus, bau, kontrol defekasi, kekhawatiran terhadap sosial, konsep diri, dan perawatan stoma sehingga membawa pada keadaan stres berat. Dapat dipahami bahwa keberadaan stoma lebih memberikan beban terhadap psikososial 
yang membebani psikis dan sosialnya daripada beban fisik terhadap ostomate, sebagaimana Sirota (2006) menyatakan bahwa salah satu isu psikososial yang muncul pada ostomate adalah konsep diri atau harga diri. Hal ini bisa saja terjadi karena masing-masing individu memiliki kemampuan untuk membangun koping yang berbeda-beda. Dalam hal ini responden dengan stres sedang tentunya lebih memiliki strategi koping yang lebih baik daripada responden dengan stres berat.

Model stres yang diperkenalkan oleh Lazarus dan Folkman menyatakan bahwa stres sebagai respon perseptual individu yang berakar dari proses psikologis dan kognitif (Potter \& Perry, 2005). Disini kognitif berperan sebagai strategi koping, dimana Rasmun (2004) menyatakan bahwa kognitif berperan dalam mengatasi masalah atau stresor yang dihadapi dengan menggunakan pengetahuan dan pengalaman, termasuk didalamnya individu memilih dan melaksanakan alternatif untuk menyelesaikan stresor dan mengevaluasi kefektifannya, memanipulasi situasi agar tidak muncul stresor, mendisiplinkan diri untuk menghindari stresor, mensupresi perasaan yang tidak menyenangkan ke alam bawah sadar dan berserah diri pada Tuhan Yang Maha Esa.

\section{KUALITAS HIDUP}

Dari hasil penelitian pada Tabel 2 mengenai kualitas hidup responden ostomate di RSUP DR. M. Djamil Padang, lebih dari separuh responden $(64,3 \%)$ memiliki kualitas hidup yang cukup. Hal ini dapat dipengaruhi oleh penghasilan responden. Sejalan dengan pendapat Anderson dan Burckhardi (1999 dikutip dari Sulistyowati, 2006) bahwa kualitas hidup dapat dipengaruhi oleh karakteristik lingkungan salah satunya yaitu ekonomi dan dukungan sosial.

Jika dilihat dari penghasilan per bulan responden, sebanyak lebih dari separuh $(72,2 \%)$ responden dengan kualitas hidup cukup ini tidak memiliki penghasilan. Meskipun tidak memiliki penghasilan, namun lebih dari separuh responden tersebut terlihat memiliki dukungan keluarga dan sosial yang baik.

Dukungan dari keluarga dan sosial pada ostomate memfasilitasi ostomate terhadap perubahan atau perbedaan yang mereka alami. Dari hasil penelitian beberapa peneliti menyebutkan bahwa koping yang aktif, ketersediaan dukungan sosial dan sumber kesehatan yang terkait dengan status sosial ekonomi yang lebih tinggi membantu individu untuk mempertahankan atau lebih cepat untuk mengembalikan kesejahteraan setelah kemunculan beberapa perubahan (Cohen \& Wills, 1985; Schulz \& Decker, 1985 dikutip dari Smith dkk, 2007).

Dalam penelitian inipun diketahui bahwa lebih dari seperempat $(35,7 \%)$ responden memiliki kualitas hidup yang baik. Hal ini berarti responden tersebut memiliki persepsi yang baik terhadap kualitas hidupnya. Dilihat dari penghasilan per bulannya, sebanyak $80 \%$ responden tersebut memiliki penghasilan di atas UMR. Responden yang memiliki penghasilan yang lebih baik tentunya mampu menghadapi beberapa perubahan fungsi dalam hidupnya, misalnya saja dengan status sosial yang lebih baik dan memperoleh perawatan yang lebih baik orang-orang disekitar tidak memandang rendah responden. Selain itu terlihat hampir seluruh responden yang memiliki kualitas hidup yang baik ini mendapatkan dukungan keluarga dan sosial yang baik. Tentunya dengan dukungan keluarga dan sosial yang baik responden dapat menjadi lebih mudah dalam mengkoping diri dari perubahan-perubahan yang dialaminya.

Pada penelitian ini tampak bahwa adanya perbedaan dalam menjalankan ibadah antara responden yang memiliki kualitas hidup cukup dan kualitas hidup baik. Hal ini tampak dari jawaban responden dimana lebih dari separuh responden dengan kualitas hidup cukup $(68,4 \%)$ 
menjadikan keberadaan stoma sebagai penghalang dalam mereka beribadah sedangkan pada responden dengan kualitas hidup baik hanya $18,2 \%$ saja. Hal ini sejalan dengan pendapat Garofalo dkk (2006) yang menyatakan bahwa agama mampu mempengaruhi kualitas hidup.

\section{HUBUNGAN STRES DAN KUALITAS HIDUP}

Dari penelitian yang telah dilakukan diketahui terdapat hubungan positif dan sangat kuat antara stres dengan kualitas hidup pada ostomate. Berdasarkan hasil analisis data tersebut maka hipotesis peneltian yang berbunyi adanya hubungan positif antara stres dengan kualitas hidup pada ostomate dapat diterima. Hasil penelitian ini juga sesuai dengan pendapat beberapa peneliti yang menyatakan bahwa masalah psiko-sosial yang disini berperan sebagai stresor pada ostomate mampu mempengaruhi kualitas hidup (Bekkers dkk, 1996; Borwell, 1997; Huish dkk, 1998; Rozmovits, 2004 dikutip dari Sirota, 2006). Hal ini juga sejalan dengan model yang dimiliki Garofalo dkk (2006), dimana dalam modelnya tersebut juga mengemukakan bahwa stres dan kualitas hidup saling mempengaruhi.

Ada lebih dari separuh (67,9 \%) responden mengalami stres sedang namun hampir seluruh responden $(89,5 \%)$ tersebut memiliki kualitas hidup yang cukup dan hanya $10,5 \%$ responden yang memilki kualitas hidup baik. Dapat dipahami bahwa responden merasakan gangguan dan perubahan seperti bau, suara dari stoma, dan flatus yang mempengaruhi pada kehidupan biologis, psikologis, sosial, dan agamanya. Hal ini dapat dipengaruhi oleh lama stoma dan penghasilan responden. Jika dilihat dari lamanya stoma hampir dari seluruh responden $(88,2 \%)$ yang mengalami stres sedang dan memiliki kualitas hidup cukup telah memiliki stoma kurang dari 1 tahun dan dari penghasilan lebih dari separuh (70,6 \%) dari responden tersebut tidak memiliki penghasilan kemudian dari dukungan sosial tampak bahwa hampir seluruh responden ini memiliki dukungan sosial yang baik. Sedangkan pada responden yang juga mengalami stres sedang namun memiliki kualitas hidup yang baik, seluruh responden tersebut juga memiliki stoma yang kurang dari 1 tahun namun memiliki penghasilan diatas UMR serta tampak memiliki dukungan keluarga dan sosial yang cukup baik. Disini terlihat bahwa penghasilan dan dukungan sosial yang membedakan kualitas hidup pada responden yang mengalami stres sedang.

Dari 28 responden, 28,6 \% responden yang mengalami stres ringan akan keberadaan stomanya memiliki kualitas hidup yang baik. Hal ini berarti responden mampu beradaptasi terhadap stresor dengan baik dan memiliki koping yang baik sehingga perspektif responden terhadap kualitas hidupnyapun baik. Jika dilihat dari lamanya stoma walaupun separuh dari responden tersebut memiliki stoma kurang dari 1 tahun tetapi $75 \%$ responden tersebut memiliki penghasilan di atas UMR serta seluruh responden memiliki dukungan keluarga dan sosial yang baik. Dapat dimengerti bahwa kondisi ekonomi yang baik serta dukungan dari keluarga dan sosial yang baik membantu responden menghadapi stresor dan mengkoping diri lebih cepat terhadap perubahan yang dialami.

Dalam penelitian ini walaupun terdapat sebanyak 3,6 \% responden mengalami stres berat tetapi mereka memiliki kualitas hidup yang cukup. Hal ini bisa saja terjadi 
mengingat banyak faktor yang mempengaruhi seseorang dalam beradaptasi terhadap suatu perubahan, seperti faktor demografi sosial individu, dan dukungan yang telah peneliti identifikasi yaitu lama stoma, dan penghasilan sebagai sumber dukungan dalam ekonomi responden. Jika dilihat dari lamanya responden ini memiliki stoma, seluruh responden tersebut memiliki stoma kurang dari 1 tahun dan tidak memiliki penghasilan. Dari dukungan keluarga dan sosial yang didapatkannya pun tampak bahwa responden mendapatkan dukungan sosial yang terbatas. Menurut Niven (2002) dukungan sosial merupakan unsur penting dalam suatu perubahan dan keluarga berfungsi untuk memberikan dukungan terutama dukungan emosional yang dapat meningkatkan harga diri.

\section{KESIMPULAN}

Adapun kesimpulan penelitian ini adalah sebagai berikut:

1. Lebih dari separuh responden ostomate di RSUP DR. M. Djamil mengalami stres sedang.

2. Lebih dari separuh responden ostomate di RSUP DR. M. Djamil memiliki kualitas hidup yang cukup.

3. Terdapat korelasi yang sangat kuat dengan arah yang positif $(+)$ antara stres dengan kualitas hidup responden ostomate dimana semakin tinggi skor nilai stres maka semakin tinggi pulalah skor nilai kualitas hidup ostomate atau semakin berat stres yang dirasakan semakin buruk kualitas hidup yang dimiliki ostomate $(\mathrm{r}=0,826)$.

\section{UCAPAN TERIMAKASIH}

Alhamdulillah, puji syukur atas rahmat dan izin Allah SWT penelitian dan manuskrip ini dpaat diselesaikan. Terimakasih yang tak terhingga kepada kedua orang tua, rekan seprofesi dan $\mathrm{KaRu}$ Bedah dan Poli Bedah yang telah mendukung proses penelitian dan pembuatan manuskrip ini.

\section{DAFTAR PUSTAKA}

American Cancer Society. Colostomy guide. Diakses pada tanggal 31 Maret 2009 dari http://www.cancer.org/docroot/CRI/ content/CRI $26 x$ Colostomy.asp

Annells, M. (2006). The experience of flatus incontinence from a bowel ostomy: a hermeneutic phenomenology. Journal of Wound, Ostomy, and Continence Nursing, 33(5), 518-24.

Arikunto, S. (2007). Manajemen penelitian. Jakarta: PT. Rineka Cipta.

Arora, A. (2008). 5 langkah mencegah dan mengatasi stres. Jakarta: PT. Bhuana Ilmu Populer.

Azamris, Bustami, N., \& Jalins, M. (1989). Karsinoma rekti di RSUP Dr. M. Jamil Padang. Diakses pada tanggal 30 Januari 2009 dari http://www.kalbe.co.id/files/cdk/file s/17KarsinomaRektidiRSUPDr.M.J amil,Padang120.pdf/17KarsinomaR ektidiRSUPDr.M.Jamil,Padang120. html

Bartha, I., Hajdu, J., Kanyari, Z., \& Damjanovich, L. (1995). Quality of life post-colostomy patients. Orvosi Hetilap, 136(37), 8.

Blackley, P. (2004). Practical stoma wound and continence management. Vermont: Research Publication Pty. Ltd.

Cark, J. (2005). Ileostomy guide. Diakses pada tanggal 29 April 2009 dari http://www.uoaa.org/ostomy info/p ubs/uoa ileostomy en.pdf 
Clark, J., \& Grover, P. (2004). Colostomy guide. Diakses pada tanggal 29 April 2009 dari http://www.uoaa.org/ostomy info/p ubs/uoa colostomy en.pdf

Clark, J. (2006). Colostomy. Diakses pada tanggal 30 Januari 2009 dari http://wikipedia.org/wiki/Colostom y

Colquhoun, P., Kaiser, R., Efron, E.G., \& Weiss dkk. (2006). Is the quality of life better in patients with colostomy than patients with fecal incontinence?. World Journal Surgery, 30(10), 1925-8.

Dinas Kesehatan Kota Balikpapan. (2008). Kesehatan jiwa. Diakses pada tanggal 30 Januari 2009 dari http://www.dkkbpp.com/index.php?option $=$ com co ntent\&task $=$ view\&id=154\&Itemid= $\underline{47}$

Dahlan, S. (2008). Statistik untuk kedokteran dan kesehatan (ed. 3). Jakarta: Salemba Medika.

Eliss. (2008). Banyak makan sayur dan buah segar cegah resiko kanker. Diakses pada tanggal 26 April 2009 dari

http://kulitcantik.jawabali.com/ada/ cegah-kanker/

Garofalo, J.P., Hamann, H.A., Ashworth, K., \& Baum, A. (2006). Stress and quality of life in american cancer survivors. Ethnicity of Disease, 16, $732-738$.

Hawari, D. (2006). Manajemen stres, cemas dan depresi. Jakarta: Gaya Baru.

Hardjana, A. M. (1994). Stres tanpa distres. Yogyakarta: Kanistus.

Holzer, B., Klaus, M., dkk. (2005). Do geographic and educational factors influence the quality of life in rectal cancer patients with a permanent colostomy?. Disease of the Colon and Rectum, 48(12), 2209-16.

Keliat, B.A. (1994). Gangguan konsep diri. Jakarta: EGC.
Keliat, B.A. (1999). Penatalaksanaan stres. Jakarta: EGC.

Keliat, B.A. \& Sinaga, C.Th. (1994). Marah akibat penyakit yang diderita. Jakarta: Arcan.

Maguire, P., \& Parkes, C.M. (1998). Coping with loss surgery and loss of body parts. British Medical Journal, 316(7137), 1086-1088.

Martin, K.K. (1994). Enterostomal therapy nursing intervention and social adjustment of patient following ostomy surgery. (Master thesis, Texas Woman's University, 1994). Diakses dari http://proquest.umi.com/pqdweb?in $\mathrm{dex}=0 \&$ sid $=1 \&$ srchmode $=1 \&$ vinst $=$ PROD\&fmt $=6 \&$ startpage $=-$ $1 \&$ clientid $=45625 \&$ vname $=$ PQD \& $\underline{\text { RQT }}=309 \&$ did $=743279921 \&$ scalin $\mathrm{g}=\mathrm{FULL} \& \mathrm{ts}=1244630384 \& \mathrm{vtype}=$ PQD\&rqt $=309 \&$ TS $=1244630404 \&$ clientId $=45625$

Munky \& Yoga. (2005). Apa itu stres. Diakses pada tanggal 30 Januari 2009 dari http://thehohos.blogspot.com/2005/ 05/apa-itu-stress.html

National Cancer Institute. (2009). Colon and rectal cancer. Diakses pada tanggal 25 April 2009 dari http://www.cancer.gov/cancertopics /types/colon-and-rectal

Niven, N. (2002). Psikologi kesehatan pengantar untuk perawat dan profesional kesehatan lain (ed.2). Jakarta: EGC.

Notoadmodjo, S. (2005). Metodologi penelitian kesehatan. Jakarta: Rineka Cipta.

Nugent, K.P., Daniels, P., Stewart, B., Patnkar, R., \& Johson, C.D. (1999). Quality of life in stoma patients. Disease of the Colon and Rectum, 42(12), 1569-74.

Nursalam. (2003). Konsep \& penerapan metodologi penelitian ilmu keperawatam. Jakarta: Salemba Medika. 
Orsted, H. L. (2007). Health related quality of life for the person with an ostomy. Wound Care Enterostomal Therapy Journal, 27(1), 34-36.

Pachler, J., Wille, -J. P. (2004). Quality of life after rectal resection for cancer, with or without permanent colostomy. Cochrane Database of Systematic Reviews, (2). doi: 10.1002/14651858.CD004323.pub3

Potter, P.A., \& Perry, A.G. (2005). Buku ajar fundamental: keperawatan konsep, proses, dan praktik (ed 4), vol. 1. Jakarta: EGC.

Potter, P.A., \& Perry, A.G. (2006). Fundamental keperawatan: konsep, proses dan praktik (ed.2), vol. 2. Jakarta: EGC.

Priaambodo, A.P, Ibrahim, K., \& Nuraen, A. (2007). Kualitas hidup pasien yang menjalani pemasangan stoma usus di wilayah kota bandung. Diakses pada tanggal 31 Maret 2009 dari http://resources.unpad.ac.id/unpadc ontent/uploads/publikasi dosen/2C \%20isi\%20inti\%20laporan.pdf

Prieto, L., Thorsen, H., \& Juul, K. (2005). Development and validation of a quality of life questionnaire for patients with colostomy or ileostomy._Health and Quality of Life Outcomes, 3(62). doi:10.1186/1477-7525-3-62.

Rasmun. (2004). Stres, koping, dan adaptasi teori dan pohon masalah keperawatan (ed. 1). CV. Jakarta: Sagung Seto.

Smith, D.M., Loewenstein, G., Rozin, P., Sherriff, R.L., \& Ubel, P.A. (2007). Sensitivity to disgust, stigma, and adjustment to life with a colostomy. Journal of Research in Personality, 41(4), 787-803.

Sigobar. (2008). Stres dan depresi. Diakses pada tanggal 30 Januari 2009 http://www.mupeng.com/forum/sho wthread.php?t=14469

Silva, M.A., Ratnayake, G., Deen, K.L. (2003). Quality of life of stoma patients: temporary ileostomy versus colostomy. World Journal Surgery, 27, 421-424. doi: 10.1007/s00268-002-6699-4.

Sinaga, B. A. (1994). Marah akibat penyakit yang diderita. Jakarta: Arcan.

Sirota,T. (2006). Meeting the psychososial needs of ostomy patients through terapeutic interaction. Wound Care Enterostomal Therapy Journal, 26(1), 26-32.

Sugiyono. (2007). Metode penelitian administrasi. Bandung: Alfabeta.

Sulistyowati, Y. N. (2006). Kualitas hidup penderita karsinoma serviks dengan kemoterapi di RSUP DR. Sardjito Yogyakarta. Tidak dipublikasikan, Program Studi Ilmu Keperawatan Fakultas Kedokteran Universitas Gajah Mada Yogyakarta.

Taylor, C., Lillis, C., \& Mone, P.L. (1997). Fundamental of nursing (ed. 3). Philadelphia: Lippincott-Raven Publisher.

Teneyck, C. I. (1997). The relationship between the timing of selfcare information and adjustment to ostomy surgery. (Master thesis, Grand Valley State University, 1997). Diakses pada tanggal dari http://proquest.umi.com/pqdweb?in $\mathrm{dex}=0 \& \mathrm{did}=740439641 \&$ SrchMode $=1 \&$ sid $=4 \&$ Fmt $=2 \&$ VInst $=$ PROD\& VType $=$ PQD\&RQT $=309 \&$ VName $=$ PQD\&TS $=1244630764 \&$ clientId $=$ 45625

Tonosaur. (2009). Nikmat di lidah membawa petaka. Diakses pada tanggal 26 April 2009 dari http://kopipasteu.blogdetik.com/200 9/04/14/nikmat-di-lidah-membawapetaka/ 
Tseng, H.C., Wang, H.H., Hsu, Y.Y., \& Weng, W.C. (2004). Factors related to stress in outpatients with permanent colostomies. Kaohsiung Jurnal of Medical Science, 20 (2), 70-76.

United Ostomy Associations of America. (2009). What is an ostomy?. Diakses pada tanggal 29 April 2009 dari http://www.uoaa.org/ostomy info/w hatis.shtml

United Ostomy Associations of America. (2009). Spouse and family support for ostomates. Diakses pada tanggal 29 April 2009 dari http://www.uoaa.org/ostomy info/pu bs/uoa brochure spouse.pdf 